\title{
Chemical composition of Sacha Inchi (Plukenetia volubilis L.) seeds and characteristics of their lipid fraction
}

\author{
By Luis-Felipe Gutiérrez, ${ }^{a \star}$ Lina-María Rosada ${ }^{\mathrm{b}}$ and Álvaro Jiménez ${ }^{\mathrm{a}}$ \\ a Instituto de Ciencia y Tecnología de Alimentos (ICTA), Universidad Nacional \\ de Colombia. Carrera 30 No. 45-03, Bogotá D.C., Colombia. \\ ${ }^{\mathrm{b}}$ Facultad de Ingeniería, Universidad Nacional de Colombia. Carrera 30 \\ No. 45-03, Bogotá D.C., Colombia. \\ ( ${ }^{*}$ Corresponding author: Ifgutierreza @ unal.edu.co)
}

\section{RESUMEN}

Composición química de las semillas de Sacha Inchi (Plukenetia volubilis L.) y características de su fracción lipídica.

Semillas de Sacha inchi (Plukenetia volubilis L.) de Colombia fueron analizadas en su composición química. Las semillas de Sacha inchi (SIO) fueron ricas en aceite (41.4\%) y proteína $(24.7 \%)$. Los principales minerales presentes en las SIS fueron potasio (5563.5 ppm), magnesio (3210 ppm) y calcio (2406 ppm). El análisis de ácidos grasos reveló que los ácidos $\alpha$-linolénico (50.8\%) y linoleico (33.4\%) fueron los principales ácidos grasos presentes en el aceite de Sacha inchi (SIO). El fraccionamiento del SIO, realizado por extracción en fase sólida, produjo principalmente lípidos neutros (97.2\%), y bajas cantidades de ácidos grasos libres (1.2\%) y fosfolípidos $(0.8 \%)$. Las propiedades fisicoquímicas del aceite incluyen: índice de saponificación 185.2; índice de yodo 193.1; densidad $0.9187 \mathrm{~g} / \mathrm{cm}^{3}$, índice de refracción 1.4791 y viscosidad $35.4 \mathrm{mPa}$.s. Los perfiles de fusión del SIO se caracterizaron por la presencia de un ancho pico endotérmico con una entalpía de fusión de $23.2 \mathrm{~J} / \mathrm{g}$. Los resultados indican que el Sacha inchi es una importante nueva especie con aplicaciones en las industrias de alimentos y farmacéutica.

PALABRAS CLAVE: Ácidos grasos - DSC - Perfiles de fusión - Plukenetia volubilis - Propiedades de aceites - Sacha Inchi.

\section{SUMMARY}

Chemical composition of Sacha Inchi (Plukenetia volubilis L.) seeds and characteristics of their lipid fraction.

The seeds of Sacha inchi (Plukenetia volubilis L.) from Colombia were analyzed for their main chemical composition. Sacha inchi seeds (SIS) were rich in oil (41.4\%) and protein $(24.7 \%)$. The main minerals present in SIS were potassium (5563.5 ppm), magnesium (3210 ppm) and calcium (2406 ppm). A fatty acid analysis revealed that $\alpha$-linolenic (50.8\%) and linoleic (33.4\%) acids were the main fatty acids in Sacha inchi oil (SIO). The lipid fractionation of SIO, obtained by solid phase extraction, yielded mainly neutral lipids $(97.2 \%)$, and lower amounts of free fatty acids (1.2\%) and phospholipids $(0.8 \%)$. The physicochemical properties of the oil include: saponification number 185.2; iodine value 193.1; density $0.9187 \mathrm{~g} / \mathrm{cm}^{3}$, refractive index 1.4791 and viscosity of 35.4 $\mathrm{mPa}$.s. The melting profiles of $\mathrm{SIO}$ were characterized by the presence of one wide endothermic peak with a melting enthalpy of $23.2 \mathrm{~J} / \mathrm{g}$. Our results indicate that Sacha inchi is an important new crop with applications in the food and pharmaceutical industries.

KEY-WORDS: DSC - Fatty acids - Melting profiles - Oil properties - Plukenetia volubilis - Sacha Inchi.

\section{INTRODUCTION}

Sacha inchi (Plukenetia volubilis L.), also named "Inca Peanut", "wild peanut", "Inca inchi" or "mountain peanut", is a plant of the Euphorbiaceae family, which grows in the Amazonian forest. This plant, widely cultivated in Peru, has been a component of the diet of various native tribal groups of the region (Hamaker et al., 1992). Nowadays it is widely cultivated in the south of Colombia, and is regarded as a promising new crop. The seeds of Sacha inchi are of great interest because of their high oil content (35-60\%), which contains elevated levels of linolenic and linoleic acids, and consequently has a great potential for applications in the food and pharmaceutical industries. Linolenic $(\omega-3)$ and linoleic $(\omega-6)$ acids reach about $45 \%$ and $35 \%$ of total fatty acids (FA), respectively, whereas other FA such as oleic, palmitic and stearic, are also present in minor proportions (Hamaker et al., 1992). Thus, similar to linseed, Sacha inchi oil (SIO) is an important source of the healthy $n-3$ linolenic and $n-6$ linoleic acyl groups, which are important in the prevention of coronary heart disease and hypertension, showing a hypocholesterolemic effect when used as food supplements (Follegatti-Romero et al., 2009).

The protein content of Sacha inchi $(\sim 27 \%)$ is similar to that present in other oil seeds such as soybean, cottonseed and sunflower. According to Hamaker et al. (1992), the amino acid profile of Sacha inchi includes phenylalanine + tyrosine $(79 \mathrm{mg} / \mathrm{g})$, leucine $(64 \mathrm{mg} / \mathrm{g})$, tyrosine $(55 \mathrm{mg} / \mathrm{g})$, isoleucine (50 $\mathrm{mg} / \mathrm{g})$, lysine $(43 \mathrm{mg} / \mathrm{g})$, threonine $(43 \mathrm{mg} / \mathrm{g}$ ) and valine $(40 \mathrm{mg} / \mathrm{g})$, and is comparable to, and in some respects better than that of other oilseeds.

To the best of our knowledge, the chemical composition of Sacha inchi from Colombia has 
not been studied, and since this plant could be an opportunity for replacing the economic dependence on coca cultivation in some Amazonian regions, the aim of this study was to investigate the chemical properties of Sacha Inchi seeds and their lipid fraction, in order to find some new industrial applications for this emerging new crop.

\section{MATERIALS AND METHODS}

\subsection{Sacha inchi seeds}

Sacha Inchi seeds (SIS) from Florencia (Caquetá, Colombia) were packed under vacuum in plastic bags, and stored at $-40^{\circ} \mathrm{C}$ until the beginning of the experiments. After shelling, the seeds were ground to pass a $1 \mathrm{~mm}$ screen, using a stainless steel rotary cheese grater. These ground seeds were used for the proximate analysis, and were the raw material for oil extractions.

\subsection{Proximate analysis}

Nitrogen content was determined using the Kjeldahl method and multiplied by a factor (6.25) to determine the crude protein content. Moisture content was determined by drying the seed samples at $105^{\circ} \mathrm{C}$ to a constant weight. Ash was determined by the incineration of about $1.5 \mathrm{~g}$ of ground defatted SIS placed in a muffle furnace, maintained at $550^{\circ} \mathrm{C}$ for about $5 \mathrm{~h}$. The total lipid content was determined following an extraction procedure adapted from Christie (1982). Samples of SIS were homogenized with chloroform/methanol $(1: 1, \mathrm{v} / \mathrm{v})$ in a $1 / 10(\mathrm{~m} / \mathrm{v})$ proportion. The mixture was filtered, and the obtained solid residue was homogenized with chloroform in a $1 / 5(\mathrm{~m} / \mathrm{v})$ proportion. The filtrate was transferred into a separatory funnel and the solid was extracted once again under the same conditions, and filtered. A KCl solution $0.88 \%$ (about one quarter of the total volume of the filtrate) was added to the combined filtrates, and the resultant mixture was thoroughly shaken and settled overnight. The lower layer containing the lipids was removed from the funnel, and subsequently, the solvent was evaporated using a rotating evaporator (Model LE, Büchi, Switzerland). The obtained crude fat was collected, evaporated under nitrogen and weighed. The total carbohydrate content was determined by difference, i.e., 100 - (sum of percentages of moisture, ash, protein and lipids) (Oshodi, 1992). The energy content was determined by multiplying the percentages of crude protein, crude fat and total carbohydrate by the factors of 4.0, 9.0 and 4.0, respectively, taking the sum of the products and expressing the result in kilocalories per $100 \mathrm{~g}$ sample (Osborne and Voogt, 1978).

\subsection{Mineral analysis}

Ground seed samples ( $1.0 \mathrm{~g})$ were digested with concentrated $\mathrm{HNO}_{3}$ and perchloric acid (4:1 $\mathrm{v} / \mathrm{v}$ ) and thereafter transferred and diluted to 100
$\mathrm{mL}$ with $\mathrm{HNO}_{3}(1 \mathrm{~mL})$ and deionized water. Minerals (Mg, Zn, Cu, Fe, Ca, Na and K) were measured by atomic absorption using a Varian spectrophotometer (Varian AA240, USA) equipped with an autosampler (VARIAN SPS3, Australia), previously calibrated with standard solutions containing known amounts of the minerals being determined, using analytical grade reagents. Monometallic hollow cathode lamps were employed for each element analyzed. $\mathrm{KCl}$ (2000 ppm) and $\mathrm{NaCl}$ solutions (5000 ppm) were used as ionization suppressors for $\mathrm{Mg}, \mathrm{Zn}, \mathrm{Cu}, \mathrm{Fe}$, $\mathrm{Ca}$ and $\mathrm{Na}$, and $\mathrm{K}$ analyses, respectively.

\subsection{Oil extraction with hexane}

Oil extraction was conducted using a Soxhlet apparatus for about $5 \mathrm{~h}$ with hexane as solvent at a solid to solvent ratio of $1 / 7 \mathrm{~m} / \mathrm{v}$. After the extraction process, the flask contents were filtered, and the liquid fraction containing the lipid extract and solvent was poured into a $250-\mathrm{mL}$ flask of a rotary film evaporator to remove the solvent. The obtained oil was collected, evaporated under nitrogen, weighed, and stored in sealed amber glass vials at $-20^{\circ} \mathrm{C}$ until analysis.

\subsection{Physicochemical properties of Sacha inchi seed oil}

The density of SIO was determined picnometrically at $20^{\circ} \mathrm{C}$ according to AOAC Official Method 9201.212 (AOAC International, 1999). Refractive index was measured at $25^{\circ} \mathrm{C}$ according to AOAC Official Method 921.08 (AOAC International, 1990), using a Euromex Holland Abbé refractometer. lodine and saponification values were calculated according to AOAC Official Methods 920.185 and 920.160 (AOAC International, 1999), respectively. Absorbance properties of $2.0 \% \mathrm{v} / \mathrm{v}$ SIO solutions in hexane were measured using a UV/VIS spectrophotometer (JASCO V-530, Japan). Viscosity was determined at $20 \pm 0.1^{\circ} \mathrm{C}$ with a rotational rheometer (Haake Rotovisco, model RV20), using the sensor system NV.

\subsection{Thermal properties of Sacha inchi seed oil}

The melting profiles of crude SIO were determined using a differential scanning calorimeter (DSC 2910 TA Instruments, TA Instruments Co., New Castle, $\mathrm{DE})$ equipped with a refrigerated cooling system and a modulate DSC (MDSC) system (TA Instruments, USA). The system was purged during analysis with nitrogen at $30 \mathrm{~mL} / \mathrm{min}$. Samples $(\sim 10 \mathrm{mg})$ were cooled at $-50^{\circ} \mathrm{C}$, held and this temperature for $5 \mathrm{~min}$, and then heated at $5^{\circ} \mathrm{C} / \mathrm{min}$ until reaching $40^{\circ} \mathrm{C}$. Calibration of DSC was carried out using indium (m.p. $=156.6^{\circ} \mathrm{C}, \Delta H_{f}=28.71 \mathrm{~J} / \mathrm{g}$ ). Data were analyzed using thermal analysis software (TA Instruments Universal Analysis Version 2.5, TA Instruments, USA). The solid fat content (SFC) was determined from the DSC melting curves by the sequential integration of peak areas, as indicated by Deroanne 
(1977) and Lambelet (1983). The heat capacity of SIO was measured using the MDSC option, as suggested by Zanier and Jäckle (1991).

\subsection{Fatty acid composition}

The fatty acid composition of the SIO was determined by GC. The oil was converted into methyl esters (FAME) and analyzed on an Agilent model 7890A gas chromatograph (Santa Clara, $\mathrm{CA})$. The oven temperature was programmed as follows: from $60^{\circ} \mathrm{C}$ (isothermal for $1 \mathrm{~min}$ ) to $190^{\circ} \mathrm{C}$ at $20^{\circ} \mathrm{C} / \mathrm{min}$, and isothermal period of $30 \mathrm{~min}$ at $190^{\circ} \mathrm{C}$. The injector and detector temperatures were set at $250^{\circ} \mathrm{C}$. Helium was used as carrier gas. GC separation peaks was performed on a BPX70 capillary column $(60 \mathrm{~m} \times 0.25 \mathrm{~mm}$ i.d. $\times 0.25 \mu \mathrm{m}$ film thickness; SGE, Melbourne, Australia). Fatty acids were identified by comparing their retention times with those of the FAME standards purchased from Sigma Aldrich (St. Louis, MO, USA) under the same conditions. Peaks were integrated using Agilent ChemStation software.

\subsection{Lipid classes}

Separation of individual lipid fractions was achieved using solid-phase extraction (SPE) cartridges (ExtractClean $\mathrm{NH}_{2}$ SPE Columns, Alltech, Deerfield, IL, USA) as described by Oomah et al. (2000). The cartridges were preconditioned with 2-mL methanol, 2-mL chloroform, and 4-mL hexane, and then, about $150 \mathrm{mg}$ of SIO dissolved in chloroform were injected using a micropipette. Lipid fractions were recovered by sequential elution with $4-\mathrm{mL}$ each of chloroform/ isopropanol (2/1, v/v), diethyl ether/acetic acid (95/5, $\mathrm{v} / \mathrm{v}$ ), and methanol, to separate neutral lipids, free fatty acids and phospholipids, respectively. The collected eluted fractions were evaporated under nitrogen, weighed, and analyzed for fatty acid composition.

\subsection{Expression of results and statistical analysis}

All assays were carried out at least in duplicate. Data were reported as mean \pm standard deviation. Mean comparisons were conducted by the least significant difference (LSD) test, using the Statistical Analysis System (SAS Institute, 2000).

\section{RESULTS AND DISCUSSION}

\subsection{Chemical composition of Sacha Inchi seeds}

The average composition of SIS is presented in Table 1. As seen in this table, the moisture content of SIS $(3.3 \pm 0.3 \%)$ was within the range of $0-13 \%$ reported to be suitable for storage and processing without microorganism degradation of the triacylglycerols (James, 1995).
As expected, SIS were rich in oil $(41.1 \pm 0.4 \%$ $(w / w))$ and crude protein $(24.7 \pm 0.5 \%(w / w))$. The oil extraction yields obtained with hexane $(42.0 \pm 1.1 \%)$ were slightly higher but not significantly different than those reached using chloroform-methanol, indicating a low content of polar lipids, such as phospholipids, in the investigated seeds (Gutiérrez et al., 2008). The oil content obtained in this study was within the interval reported by Guillén et al. (2003) for SIS (35-60\%), higher than that obtained by Bondioli and Della Bella (2006) (34.42\%), but lower than those reported by Hamaker et al. (1992) and recently by Follegatti-Romero et al. (2009) $(\sim 54 \% \mathrm{w} / \mathrm{w})$. Differences in the oil content of seeds could be attributed to the different subspecies, geographical and climate conditions, harvesting time of the seeds, as well as the extraction method (Yang and Kallio, 2002). Since the oil content of SIS was comparable with those of other seeds such as flaxseed (41\%) (Morris and Vaisey-Genser, 2003), safflower (30-40\%) (Smith, 2007), canola (38-44\%) (Przybylski et al., 2007) and peanut (44$56 \%$ ) (Pattee, 2007), the commercial production of SIO could be economically viable, taking into account the increasing demand for oils with a high content of essential fatty acids, due to their importance in preventing cardiovascular diseases and hypertension.

The protein content of the SIS analyzed in this study was slightly lower than that reported by Hamaker et al. (1992) (27\% w/w), and similar to those published for sesame seed ( 25\%) (Hwang, 2007), peanut $(23 \% \mathrm{w} / \mathrm{w})$ and sunflower $(24 \% \mathrm{w} / \mathrm{w})$ (Bodwell and Hopkins, 1985). These data suggest that if the protein is well digested, SIS could contribute to the daily protein need for adults ( $0.66 \mathrm{~g} / \mathrm{kg}$ per day), as recommended by the World Health Organization (2007).

SIS contains a relatively low value of total carbohydrate $(30.9 \%)$, due to the high levels of crude oil and protein. The calorific value of SIS, calculated from the contents of fat, protein and carbohydrate, was $576 \mathrm{kcal} / 100 \mathrm{~g}$ sample. Therefore, consuming SIS at 140-200 g per day would give energy values recommended by the Food and Agriculture Organization's (800-1200 kcal/day) (FAO, 1973).

\subsection{Mineral composition of seeds}

The mineral content of SIS is presented in Table 1. The data show that SIS contains significant amounts of dietary essential minerals, such as magnesium (3210 mg/kg), calcium (2406 mg/kg), and zinc $(49 \mathrm{mg} / \mathrm{kg})$, and suggest that SIS could be used in the human diet for supplying these elements. Potassium was the most abundant mineral found in SIS $(5563.5 \mathrm{mg} / \mathrm{kg})$, while minor amounts of iron $(103.5 \mathrm{mg} / \mathrm{kg})$, sodium $(15.4 \mathrm{mg} /$ $\mathrm{kg})$ and copper $(12.9 \mathrm{mg} / \mathrm{kg})$ were also presents. Although the soil composition is a factor influencing the mineral composition of seeds, when comparing with other seed oils such as cottonseed, linseed, peanut and safflower (Blackwood, 2007), SIS show 
Table 1

Chemical composition of the Sacha Inchi (Plukenetia volubilis L.) seeds and physicochemical properties of their crude oil ${ }^{a}$

\begin{tabular}{|c|c|}
\hline Component & Value \\
\hline \multicolumn{2}{|l|}{ Seeds } \\
\hline Moisture (\%) & $3.3 \pm 0.3$ \\
\hline Fat $(\%)$ & $42.0 \pm 1.1$ \\
\hline Protein (\%) & $24.7 \pm 0.5$ \\
\hline Ash (\%) & $4.0 \pm 0.7$ \\
\hline Total carbohydrate (\%) & $30.9 \pm 0.6$ \\
\hline Potassium (mg/kg) & $5563.5 \pm 6.4$ \\
\hline Magnesium (mg/kg) & $3210.0 \pm 21.2$ \\
\hline Calcium (mg/kg) & $2406.0 \pm 7.1$ \\
\hline Iron $(\mathrm{mg} / \mathrm{kg})$ & $103.5 \pm 8.9$ \\
\hline Zinc (mg/kg) & $49.0 \pm 1.1$ \\
\hline Sodium (mg/kg) & $15.4 \pm 0.5$ \\
\hline Cooper (mg/kg) & $12.9 \pm 0.3$ \\
\hline \multicolumn{2}{|l|}{ Crude oil } \\
\hline lodine value $\left(\mathrm{g} \mathrm{I}_{2} / 100 \mathrm{~g}\right)$ & $193.1 \pm 1.0$ \\
\hline Saponification value $(\mathrm{mg} \mathrm{KOH} / \mathrm{g})$ & $185.2 \pm 0.5$ \\
\hline Refractive index at $25^{\circ} \mathrm{C}$ & $1.4791 \pm 0.0009$ \\
\hline Density at $25^{\circ} \mathrm{C}\left(\mathrm{g} / \mathrm{cm}^{3}\right)$ & $0.9187 \pm 0.02$ \\
\hline Viscosity at $20^{\circ} \mathrm{C}$ (mPaxs) & $35.4 \pm 0.4$ \\
\hline
\end{tabular}

${ }^{a}$ Values are means \pm standard deviations of triplicate determinations.

the highest concentration of $\mathrm{Zn}$, and the lowest content of $\mathrm{Na}, \mathrm{Cu}$ and $\mathrm{Fe}$. The levels of calcium were similar to those reported by Smith (2007) for safflower seeds (2406 vs. $2140 \mathrm{mg} / \mathrm{kg}$ ).

\subsection{Physicochemical properties of Sacha inchi oil}

Table 1 presents the physicochemical properties of the hexane extracted SIO. The bright yellow oil had a density value of $0.9187 \mathrm{~g} / \mathrm{cm}^{3}$ at $25^{\circ} \mathrm{C}$, which was slightly higher than those reported for other vegetable oils such as corn oil, cottonseed oil and soybean oil, because of the high unsaturation degree of SIO. The refractive index of SIO (1.4791 at $25^{\circ} \mathrm{C}$ ) was higher than those of other vegetable oils such as corn oil, soybean oil and sunflower oil, because the refractive index increases as the number of double bonds increases (O'Brien et al., 2007). The saponification (185.2 $\mathrm{mg} \mathrm{KOH} / \mathrm{g}$ ) and iodine $\left(193.3 \mathrm{~g} \mathrm{I}_{2} / 100 \mathrm{~g}\right.$ ) values of SIO were similar to those recently reported by Follegatti-Romero et al. (2009) (193 mg KOH/g and $198 \mathrm{~g} \mathrm{I}_{2} / 100 \mathrm{~g}$, respectively) for crude $\mathrm{SIO}$ extracted using hexane and supercritical $\mathrm{CO}_{2}$. The viscosity of $\mathrm{SIO}$ was relatively high (35.4 $\mathrm{mPa} . \mathrm{s})$, as a consequence of its high content of unsaturated fatty acids.

Figure 1 presents the ultraviolet spectra of SIO. As can be seen in this figure, Sacha inchi seed oil showed absorbance in the UV-C (200-290 nm) and UV-B (290-320 $\mathrm{nm}$ ) range, as well as negligible absorbance in the UV-A (320-400 nm). Absorbance in the 600 - $750 \mathrm{~nm}$ range was insignificant, indicating a negligible content of green pigments (Oomah et al., 2000). SIO showed two absorbance peaks between 210 and $340 \mathrm{~nm}$, whose maximum absorbance were at about 230 and $280 \mathrm{~nm}$, respectively. Due to the relatively low absorbance shown in the UV-B, and because the wavelengths of the ultraviolet light are responsible for most of the cellular damage (Oomah et al.,2000), the SIO could not be a very good blocker against UV-B radiation at useful concentrations.

\subsection{Fatty acid composition}

The fatty acid composition of SIO extracted with hexane is presented in Table 2 . No significant differences were found with the fatty acid composition of SIO obtained using chloroform methanol. As it can be appreciated in Table 2, SIO has a unique fatty acid profile, being very rich in $\alpha$-linolenic (50.8\%) and linoleic (33.4\%) acids, with low levels of oleic $(9.1 \%)$, palmitic $(4.4 \%)$ and stearic $(2.4 \%)$ acids. Similar values were recently reported by Follegatti-Romero et al. (2009) for SIO extracted with hexane and supercritical $\mathrm{CO}_{2}$, and by Hamaker et al. (1992), except for $\alpha$-linolenic acid, which was higher in this study (50.8 vs. $45.2 \%)$. These differences could be attributed to the different subspecies, geographical and climate conditions, 


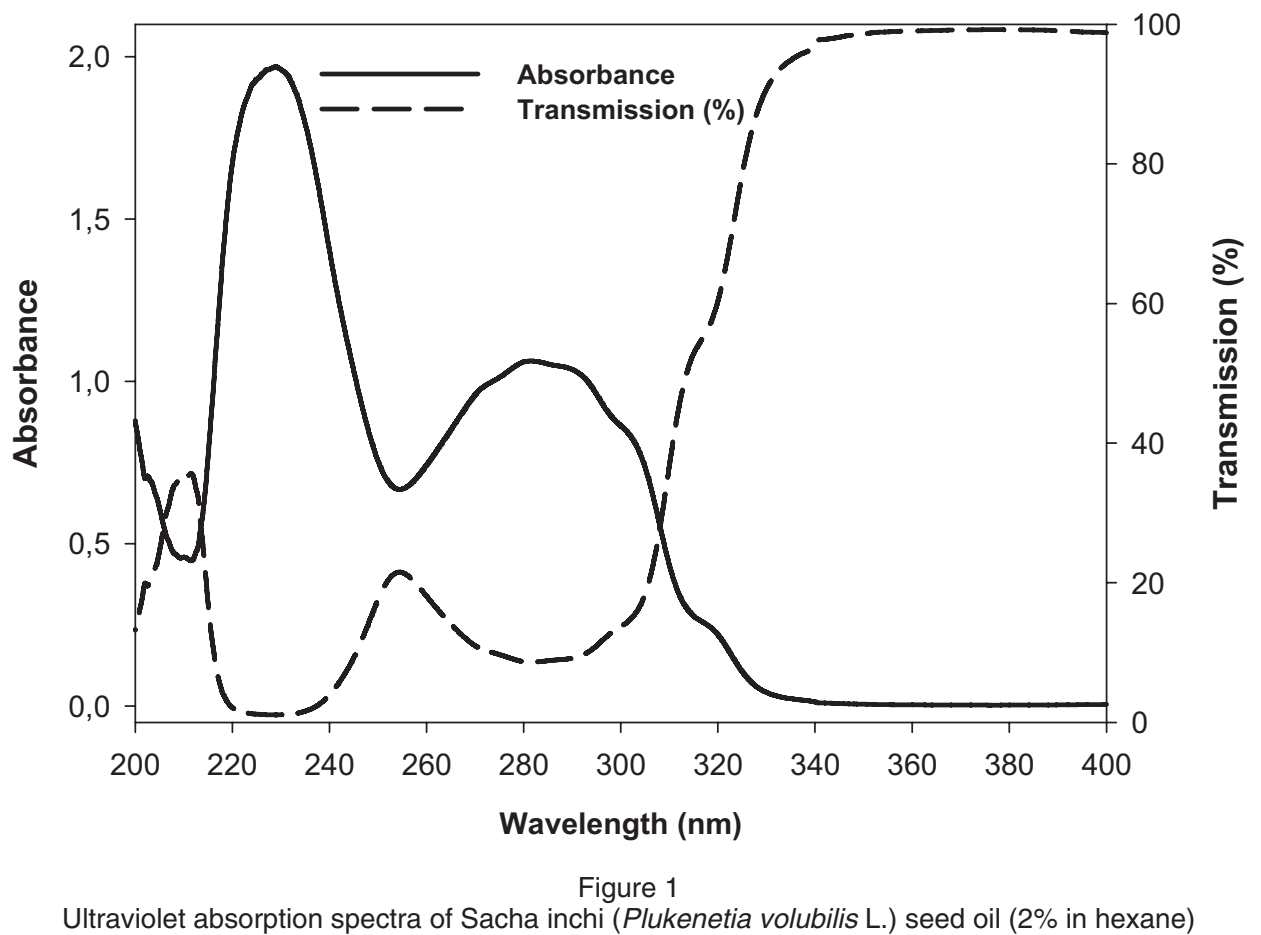

harvesting time of the seeds (Yang and Kallio, 2002), as well as to the quantification method used in the analysis. The fatty acid profile of SIO was relatively similar to that of the seabuckthorn seed oil (Gutiérrez et al., 2008), except for the content of $\alpha$-linolenic acid, which was higher in SIO. On the other hand, when comparing with linseed oil (Morris and Vaisey-Genser, 2003), the content of linoleic acid in SIO was about twice that of linseed oil (33.4 vs. $16 \%$ ), whereas the concentration of $\alpha$-linolenic was slightly lower (50.8 vs. 57\%). Taking into account that the optimal dietary intake of $\alpha$-linolenic has been suggested to be about $2 \mathrm{~g} /$ day in order to achieve essential amounts and cardiovascular benefits (Gebauer et al., 2006), SIO could be used as a source of this essential fatty acid, and be considered in the elaboration of food supplements.

Polyunsaturated fatty acids (PUFA) of the SIO amounted to about $84 \%$ of the total fatty acids, while the monounsaturated (MUFA) and saturated (SFA) fatty acids were about $9 \%$ and $7 \%$, respectively. Even though the high ratios of PUFA/ MUFA and PUFA/SFA are very good for human health, they could make the SIO very susceptible to oxidation. However, recent studies by FollegattiRomero et al. (2009) indicate that SIO contains high amounts of $\gamma$ - and $\delta$-tocopherols (1.14 and $1.25 \mathrm{~g} /$ $\mathrm{kg}$, respectively), which could increase resistance against oxidation because they are the most active antioxidants in lipids.

\subsection{Lipid classes obtained by SPE}

As shown in Table 2, the SIO consisted mainly of neutral lipids (NL) ( 97\%), with minor amounts of free fatty acids (FFA) $(\sim 2 \%)$ and phospholipids (PL) $(\sim 1 \%)$. These values are in agreement with those of common edible oils such as canola,

Table 2

Fatty acid composition in crude and in lipid fractions of Sacha inchi (Plukenetia volubilis L.) oil ${ }^{a, b}$

\begin{tabular}{|c|c|c|c|c|}
\hline Fatty acid & Crude oil & NL & FFA & PL \\
\hline Fractions (\%) & 100 & $97.2 \pm 0.9^{a}$ & $1.2 \pm 0.7^{b}$ & $0.8 \pm 0.4^{c}$ \\
\hline C16:0 (Palmitic) & $4.4 \pm 0.02^{a}$ & $4.4 \pm 0.02^{a}$ & $5.2 \pm 0.2^{b}$ & $26.9 \pm 0.5^{c}$ \\
\hline C18:0 (Stearic) & $2.4 \pm 0.02^{a}$ & $2.3 \pm 0.15^{a}$ & $3.0 \pm 0.1^{b}$ & $11.7 \pm 0.3^{c}$ \\
\hline C18:1n-9 (Oleic) & $9.1 \pm 0.01^{a}$ & $9.1 \pm 0.04^{a}$ & $9.4 \pm 0.08^{b}$ & $9.6 \pm 1.5^{c}$ \\
\hline C18:2 (Linoleic) & $33.4 \pm 0.04^{a}$ & $32.9 \pm 0.02^{b}$ & $32.3 \pm 0.1^{c}$ & $40.3 \pm 2.7^{d}$ \\
\hline C:18:3 ( $\alpha$-Linolenic) & $50.8 \pm 0.03^{a}$ & $51.2 \pm 0.10^{b}$ & $50.1 \pm 0.1^{c}$ & $11.5 \pm 1.3^{d}$ \\
\hline
\end{tabular}

${ }^{a}$ Values are means \pm standard deviations of duplicate determinations. ${ }^{b}$ Means in the same row followed by the same letter are not significantly different by LSD test. 
soybean and sunflower (Oomah et al., 2000). The fatty acid profile of the NL fraction was similar to the corresponding crude SIO, because of the quantitative primacy of this fraction in the oil. The FFA fraction showed relatively similar values of all the fatty acids identified, except for palmitic acid, which was higher in this fraction than in crude SIO $(p<0.05)$. The PL fraction of $\mathrm{SIO}$ was in general richer in palmitic, stearic, oleic and linoleic acids, and poorer in $\alpha$-linolenic acid, than in crude SIO. Significant differences $(p<0.05)$ were found for all the fatty acids identified in the PL fraction, when comparing with the crude SIO. Despite the low quantities of FFA and PL fractions in SIO, they should be removed for edible applications because of their detrimental effects on oil quality (Oomah et al., 2000).

\subsection{Thermal properties of Sacha inchi oil}

As depicted in Figure 2a, the melting behavior of the crude SIO was characterized by the presence of two overlapping peaks. One minor low-temperature endothermic transition at about $-45^{\circ} \mathrm{C}$, followed by one prominent endothermic transition at $-18.5^{\circ} \mathrm{C}$ with a melting enthalpy of $23.2 \pm 1.4 \mathrm{~J} / \mathrm{g}$, corresponding to the melting of the major triacylglycerol fractions present in the oil. The melting enthalpy of crude SIO was lower than those reported by Tan and Che Man (2002) for various vegetable oils, but is in agreement with its high content of unsaturated fatty acids.

The solid fat content of SIO, calculated from corresponding thermograms by sequential peak integration areas, indicated that it decreased as temperature increased. As seen in Figure 2a, SIO
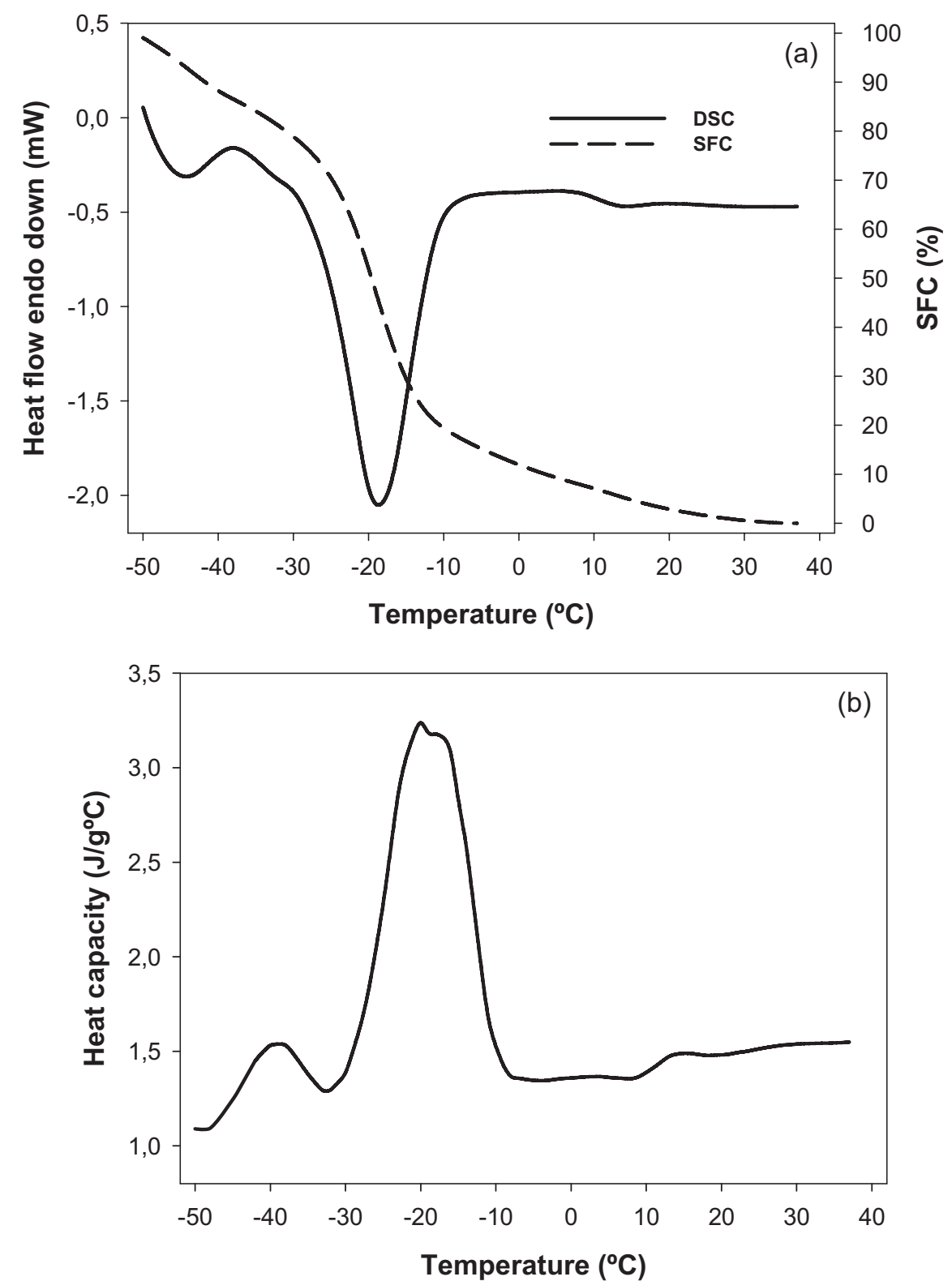

Figure 2

Thermal properties of the crude Sacha inchi (Plukenetia volubilis L.) seed oil: (a) DSC Melting curve and solid fat content (SFC), and (b) Heat capacity as a function of temperature. 
melted completely at temperatures above $-5^{\circ} \mathrm{C}$, due to its highly unsaturated nature.

Figure $2 b$ presents the heat capacity of hexane extracted SIO. As shown in this figure, the specific heat capacity for the crude SIO ranged from 1.1 to $3.2 \mathrm{~J} / \mathrm{g}^{\circ} \mathrm{C}$ in the investigated temperature range (between -50 and $40^{\circ} \mathrm{C}$ ). Similar values have been reported for high unsaturated fish oils, such as salmon oil (Sathivel, 2005), and for other vegetable oils such as soybean, linseed, cotton seed, rapeseed, safflower and peanut (Tochitani and Fujimoto, 2001).

\section{CONCLUSIONS}

Seeds of Sacha inchi from Colombia were characterized by high oil and protein contents (41.4 and $24.7 \%$, respectively). The oil, composed mainly of neutral lipids, contains important quantities of essential fatty acids ( $\omega-3$ and $\omega-6)$, which reached 50.8 and $33.4 \%$ of total fatty acids, respectively. This high content of $\omega-3$ and $\omega-6$ fatty acids gives SIS the opportunity to be employed in the manufacture of high value added products, such as capsules of essential fatty acids, and to start up innovative processes to produce conjugated linoleic acid and conjugated linolenic acid, which have been reported to have excellent properties for human health. SIS also encloses essential minerals such as magnesium calcium, and zinc, in amounts that could be used in the human diet for supplying these elements. Therefore, Sacha inchi could be used in the food and pharmaceutical industries, because of an increasing tendency towards functional foods and nutraceutical products. However, because of the high unsaturation degree of SIO, further investigations are needed for determining its oxidative stability, although recent studies indicate a high content of tocopherols that could act as antioxidant agents. For the first time, the thermal properties of SIO are reported. SIO exhibited two thermal structural transitions between -50 and $-5^{\circ} \mathrm{C}$. In the investigated temperature range, the specific heat capacity does not vary substantially (between 1.1 and $3.2 \mathrm{~J} / \mathrm{g}^{\circ} \mathrm{C}$ ), and these values could be used for industrial engineering or technological processes.

\section{ACKNOWLEDGMENTS}

This research was funded by the Instituto de Ciencia y Tecnología de Alimentos (ICTA) of the Universidad Nacional de Colombia. The authors thank Francisco Javier Ortiz for providing the Sacha Inchi seeds, Martha Sofía Franco for her technical assistance on GC analysis, and Ariel Cadena and Nathalia Rocío Henao for their technical assistance on atomic absorption spectrophotometry.

\section{REFERENCES}

AOAC International. 1990. Method 921.08, in Helrich K (Ed.) Official Methods of Analysis of the AOAC International, 15th ed, vol 2. Arlington, USA.
AOAC International. 1999. Method 9201.212, in Cunniff $P$ (Ed.) Official Methods of Analysis of AOAC International, 16th ed, Gaithersburg, USA.

Blackwood I. 2007. Mineral content of common ruminant stockfeeds, crops and pastures. NSW Department of Primary Industries (DPI). Primefact 522.

Bodwell CF, Hopkins DT. 1985. Nutritional characteristics of oilseed proteins. In Altschul AA and Wilcke HL (Ed.) New Protein Foods, vol 5: Seed Storage Proteins. Academic Press, Orlando, USA.

Bondioli P, Della Bella L. 2006. Alpha linolenic acid rich oils. Composition of Plukenetia volubilis (Sacha inchi) oil from Peru. La Rivista Italiana Delle Sostanze Grasse 83, 120-123.

Christie WW. 1982. Lipid analysis: Isolation, separation, identification and structural analysis of lipids, 2nd ed. Pergamon Press, Oxford, UK.

Deroanne C. 1977. L'analyse calorimétrique différentielle, son intérêt pratique pour le fractionnement de l'huile de palme et la détermination de la teneur en phase solide. LWT 10, 251-255.

FAO. (1973). Energy and protein requirement. Geneva, Switzerland.

Follegatti-Romero LA, Piantino CR, Grimaldi R, Cabral FA. 2009. Supercritical $\mathrm{CO}_{2}$ extraction of omega-3 rich oil from Sacha inchi (Plukenetia volubilis L.) seeds. J. Supercrit. Fluid. 49, 323-329.

Gebauer SK, Psota TL, Harris WS, Kris-Etherton PM. 2006. $n-3$ Fatty acid dietary recommendations and food sources to achieve essentiality and cardiovascular benefits. Am. J. Clin. Nutr. 83, 1526S-1535S.

Guillén MD, Ruiz A, Cabo N, Chirinos R, Pascual G. 2003. Characterization of sacha inchi (Plukenetia Volubilis L.) oil by FTIR spectroscopy and HNMR comparison with linseed oil. J. Am. Oil Chem. Soc. 80, 755-762.

Gutiérrez L-F, Ratti C, Belkacemi K. 2008. Effects of drying method on the extraction yields and quality of oils from Quebec sea buckthorn (Hippophaë rhamnoides L.) seeds and pulp. Food Chem. 106, 896-904.

Hamaker BR, Valles C, Gilman R, Hardmeier RM, Clark D, Garcia HH, Gonzales AE, Kohlstad I, Castro M, Valdivia R, Rodriguez T, Lescano M. 1992. Amino acid and fatty acid profiles of the Inca Peanut (Plukenetia Volubilis). Cereal Chem. 69, 461-463.

Hwang LS. 2007. Sesame oil. In Shahidi F (Ed.) Bailey's Industrial Oil and Fat Products, 6th ed, Part 2 Edible Oil \& Fat Products: Edible Oils. John Wiley \& Sons, Inc. New York, USA.

James CS. 1995. Analytical chemistry of foods. Chapman and Hall publishers, New York, USA.

Lambelet P. 1983. Comparison of NMR and DSC methods for determining solid content of fats application to milkfat and its fractions. LWT 16, 90-95.

Morris DH, Vaisey-Genser M. 2003. Flaxseed. In Caballero B (Ed.) Encyclopedia of Food Sciences and Nutrition. Academic Press, New York, pp. 2525-2531.

O'Brien RD, Jones LA, King CC, Wakelyn PJ, Wan PJ. 2007. Cottonseed oil. In Shahidi F (Ed.) Bailey's Industrial Oil and Fat Products, 6th ed, Part 2 Edible Oil \& Fat Products: Edible Oils. John Wiley \& Sons, Inc. New York, USA.

Oomah BD, Ladet S, Godfrey DV, Liang J, Girard B. 2000. Characteristics of raspberry (Rubus idaeus L.) seed oil. Food Chem. 69, 187-193.

Osborne DR, Voogt P. 1978. Calculation of calorific value, in The analysis of nutrients in foods. Academic Press, London, New York, pp. 239-240.

Oshodi AA. 1992. Proximate composition, nutritionally valuable minerals and functional properties of Adenopus 
breviflorus benth seed flour and protein concentrate. Food Chem. 45, 79-83.

Pattee HE. 2007. Peanut oil. In Shahidi F (Ed.) Bailey's Industrial Oil and Fat Products, 6th ed, Part 2 Edible Oil \& Fat Products: Edible Oils. John Wiley \& Sons, Inc. New York, USA.

Przybylski R, Mag T, Eskin NAM, McDonald BE. 2007. Canola oil. In Shahidi F (Ed.) Bailey's Industrial Oil and Fat Products, 6th ed, Part 2 Edible Oil \& Fat Products: Edible Oils. John Wiley \& Sons, Inc. New York, USA.

SAS Institute. 2000. SAS/STAT User's Guide, Version 8. SAS Institute Inc., Cary, NC.

Sathivel S. 2005. Thermal and flow properties of oils from salmon head. J. Am. Oil Chem. Soc. 82, 147-151.

Smith J. 2007. Safflower oil. In Shahidi F (Ed.) Bailey's Industrial Oil and Fat Products, 6th ed, Part 2 Edible Oil \& Fat Products: Edible Oils. John Wiley \& Sons, Inc. New York, USA.
Tan CP, Che Man YB. 2002. Comparative differential scanning calorimetric analysis of vegetable oils: I. Effects of heating rate variation. Phytochem. Anal. 13, 129-141.

Tochitani Y, Fujimoto M. 2001. Measurement of specific heat capacity of vegetable oils. Netsu Bussei 15, 230-236.

World Health Organization. 2007. Protein and amino acid requirements in human nutrition: Report of a joint FAO/WHO/UNU expert consultation. WHO Technical Report Series No. 935.

Yang B, Kallio H. 2002. Effects of harvesting time on triacylglycerols and glycerophospholipids of sea buckthorn (Hippophaë rhamnoides L.) berries of different origins. J. Food Compos. Anal. 15, 143-157.

Zanier A, Jäckle HW. 1991. Heat capacity measurements of petroleum fuels by modulated DSC. Thermochim. Acta 287, 203-212.

Recibido: $12 / 4 / 10$ Aceptado: $2 / 6 / 10$ 